\title{
DAMPAK PENINGKATAN JUMLAH UANG ELEKTRONIK $(E$ - MONEY) BEREDAR TERHADAP PERTUMBUHAN EKONOMI INDONESIA PADA MASA PANDEMI COVID-19
}

\author{
Enung Suwarni \\ Prodi Bisnis Digital Universitas Persatuan Islam (UNIPI) \\ korespondensi : enung.suwarnie@gmail.com
}

\begin{abstract}
This research aims to examine and analyze the impact of increasing the amount of electronic money (e-money) in circulation on Indonesia's economic growth during the Covid-19 pandemic. This type of research is the Descriptive Study, using secondary time series data from 2020 to 2021. The data obtained from the website of Badan Pusat Statistik (BPS) and Bank Indonesia (BI), and also other resources such as journal, book, and internet. The data is analyzed by comparing the value of Gross Domestic Product (GDP) with the circulation of e-money from 2020 to 2021(July). The result of this analysis shows that the increase of e-money's circulation has not been able to increase Indonesia's economic growth during the Covid-19 pandemic. However, the Transportation and Communications sector in Gross Domestic Product (GDP) that related to digital transaction continues to the positive growth. The growth of this sector in the second quarter of 2021 is $10.59 \%$ (compare to the second quarter of 2020). From this research, it can be concluded that e-money which is actually used in digital transaction is the foundation of economic growth during the Covid-19 pandemic, so that it becomes the base for the revival of Indonesia's economic.
\end{abstract}

Keywords: Electronic Money (e-Money), Digital Transaction, Gross Domestic Product (GDP), Covid-19 Pandemic

\begin{abstract}
ABSTRAK
Penelitian ini bertujuan untuk menganalisis dampak dari peningkatan jumlah uang elektronik (e-money) beredar terhadap pertumbuhan ekonomi Indonesia pada masa pandemi Covid-19. Metode yang digunakan dalam penelitian ini adalah Analisis Deskriptif dengan menggunakan data sekunder yang diperoleh dari laman Badan Pusat Statistik (BPS) dan Bank Indonesia (BI), dari tahun 2020 hingga tahun 2021 (bulan Juli). Data pendukung lainnya berasal dari internet, jurnal, dan sumber-sumber terkait lainnya. Data dianalisis dengan cara membandingkan nilai Pendapatan Domestik Bruto (PDB) dengan peredaran jumlah uang elektronik (emoney) dari tahun 2020 hingga tahun 2021 (bulan Juli). Hasil analisis menunjukkan bahwa kenaikan jumlah uang elektronik beredar belum dapat menaikkan pertumbuhan ekonomi Indonesia. Namun demikian, Sektor Transportasi (Pengangkutan) dan Komunikasi dalam PDB dimana berhubungan dengan transaksi digital terus mengalami pertumbuhan yang positif. Pertumbuhan pada Triwulan II-202I naik sebesar 10,59\% (dibandingkan dengan Triwulan II-2020). Dari penelitian ini dapat disimpulkan bahwa transaksi digital (transaksi dengan menggunakan uang elektronik) merupakan penopang pertumbuhan ekonomi dalam masa pandemi Covid-19, sehingga menjadi landasan bangkitnya kembali ekonomi Indonesia.
\end{abstract}

Kata Kunci: Uang Elektronik, Transaksi Digital, Produk Domestik Bruto, Pandemi Covid-19

\section{PENDAHULUAN}

Pertumbuhan ekonomi Indonesia terus berkembang dari tahun ke tahun. Saat ini perkembangan ekonomi telah memasuki era Revolusi Industri 4.0, dimana hampir semua transaksi bisnis dan perbankan telah menggunakan teknologi digital dan internet (Internet of Things).

Perkembangan teknologi yang pesat ini telah memunculkan peradaban baru "cashless society" yaitu masyarakat tanpa uang tunai. Kalangan ini dalam bertransaksi tidak lagi menggunakan uang tunai sebagai alat 
pembayaran, tetapi menggunakan media lain seperti kartu kredit, kartu debit, maupun cash card.

Tumpal Manik dalam artikelnya "Analisis Pengaruh Transaksi Digitalisasi Uang Elektronik Terhadap Cashless Society dan Infrastruktur Uang Elektronik Sebagai Variabel Pemodarasi"[1] menyatakan bahwa jumlah uang elektronik beredar selama lima tahun terakhir (2015 - 2019) terus mengalami pertumbuhan yang positif. Hal ini menandakan bahwa digitalisasi pada bidang keuangan dan perbankan terus bertumbuh dan menjadi penggerak pertumbuhan ekonomi Indonesia.

Untuk mewujudkan transaksi ekonomi dan keuangan digital, Bank Indonesia (BI) terus melakukan percepatan dalam digitalisasi sistem pembayaran. Menurut data Bank Indonesia (BI) nilai transaksi digital sampai dengan Semester I tahun 2021 tumbuh 39\% (yoy). Bank Indonesia (BI) memproyeksikan nilai transaksi digital pada tahun 2021 akan tumbuh sebesar $30,1 \%$ [2]. Munculnya berbagai inovasi dalam pembayaran digital telah berhasil menaikkan nilai transaksi digital. Bank juga banyak melakukan transformasi digital untuk meningkatkan pelayanannya kepada nasabah. Uang elektronik dan alat QRIS (Quick Response Code Indonesian Standard) telah membantu semua transaksi menjadi lebih mudah, cepat, dan terjaga keamanannya[3].

World Economic Forum (Future of Jobs Survey 2018) menyatakan bahwa terdapat 4 teknologi yang akan banyak digunakan dan sangat berpengaruh terhadap bisnis perusahaan. Keempat teknologi tersebut adalah high-speed mobile internet, artifcial intelligence, big data analytics, dan cloud technology.

Transaksi digital semakin tumbuh dan meningkat sejak pandemi Covid-19 melanda Indonesia. Awal bulan Maret 2020 virus Corona resmi dinyatakan masuk ke Indonesia, dan sejak saat itu masyarakat Indonesia harus merubah semua kebiasaan hidup termasuk dalam berbisnis dan bertransaksi. Pemerintah Indonesia telah banyak melakukan inovasi teknologi guna memudahkan migrasi transaksi bisnis dari offline ke online. Pandemi Covid-19 menjadi momentum terbaik digitalisasi transaksi bisnis dan perbankan. Menteri Keuangan (Menkeu), Sri Mulyani Indrawati, menyatakan bahwa ekonomi digital sangat penting dan potensial untuk memulihkan perekonomian pasca pandemi. Dilaporkan bahwa peningkatan ekonomi digital mencapai 25\% selama pandemi Covid-19[4].

Don Tapscott dalam bukunya "The Digital Economy" menyatakan bahwa terdapat dua belas hal penting dalam ekonomi digital; Knowledge, Digitization, Virtualization, Molecularization (Small Organization), Integration/Internetworking,

Disintermediation, Convergence, Innovation, Prosumption, Immediacy, Globalization, and Discordance[5]. Salah satu hal penting dalam ekonomi digital adalah digitalisasi, dimana semua informasi bersifat digital dan mudah diakses, serta memiliki dampak besar dalam seluruh aspek kehidupan termasuk bisnis.

Penulis tertarik untuk menganalisis penggunaan uang elektronik dalam transaksi digital pada masa pandemi Covid-19 dihubungkan dengan 
pertumbuhan ekonomi Indonesia secara makro. Apakah Peningkatan transaksi digital berkolerasi positif terhadap pertumbuhan ekonomi atau hanya sebagai salah satu solusi untuk mengatasi pandemi saja. Hal ini menjadi penting untuk dikaji karena beberapa peristiwa mendasar seperti berikut ini:

(1) Menurut data Badan Pusat Statistik (BPS) pertumbuhan ekonomi Indonesia Triwulan I-2021 masih terkontraksi $0,92 \%(q t q)$.

(2) Pertumbuhan ekonomi Indonesia pada Triwulan II-2021 naik kembali hingga 7,07\% (qtq). Kenaikan ini menunjukkan tingkat kepercayaan masyarakat dan investor terhadap Pemerintah dalam penanganan pandemi Covid-19. Bank Indonesia (BI) menilai salah satu faktor yang mendorong ekonomi tumbuh 7,07 $\%$ adalah kenaikan transaksi digital selama masa pandemi Covid-19.

(3) Naiknya Sektor Transportasi dan Komunikasi pada Triwulan II-2021 (qtq) bersamaan dengan mewabahnya kembali pandemi Covid-19 dimana hampir semua transaksi bisnis dan perbankan sudah diarahkan untuk online. Jadi pertumbuhan dalam sektor ini belum tentu mencerminkan pertumbuhan ekonomi Indonesia secara makro.

(4) Konsensus pasar memperkirakan PDB akan terkontraksi kembali pada kuartal III-2021 sebesar -1,09\% (qtq), sementara secara tahunan diperkirakan terjadi kontraksi sebesar $-0,87 \%$ (yoy). Ini artinya ekonomi Indonesia masih belum stabil dan berpotensi mengalami resesi kembali. Para ekonom memperkirakan Pemberlakuan Pembatasan Kegiatan Masyarakat (PPKM) Darurat dinilai menjadi hambatan dalam pemulihan ekonomi sehingga mengalami perlambatan.

(5) Data perekonomian PMI (Purchasing Managers' Index) menunjukkan peningkatan transaksi bisnis setelah dilakukan vaksinasi Covid-19 secara massal di berbagai wilayah. Hal ini menimbulkan rasa optimisme bahwa ekonomi Indonesia akan kembali bangkit[6].

Beberapa peristiwa penting pada poin-poin di atas mengindikasikan bahwa perekonomian Indonesia belum stabil sepenuhnya. Kontraksi yang kemudian berangsur pulih, terancam mengalami perlambatan kembali karena beberapa kebijakan dalam mengatasi pandemi Covid-19 ditengarai akan memperlambat laju pertumbuhan ekonomi Indonesia. Namun melihat geliat pertumbuhan transaksi digital yang semakin berkembang pesat, diharapkan berdampak positif pada pertumbuhan ekonomi Indonesia secara makro.

\section{TINJAUAN PUSTAKA}

Menurut KBBI, Transaksi adalah persetujuan jual beli (dalam perdagangan) antara dua pihak, atau pelunasan/penyelesaian pembayaran seperti dalam bank. Berdasarkan definisi tersebut maka Transaksi Digital dapat diartikan sebagai sistem jual beli yang dilakukan secara otomatis tanpa melibatkan kertas, atau sistem pembayaran nontunai (cashless payment) baik 
menggunakan mobile banking maupun sistem pembayaran online lainnya.

Sistem transaksi digital mengotomatisasikan berbagai macam sub-sistem pembayaran billing atau tagihan seperti pembayaran listrik, PDAM, telepon, internet, BPJS, angsuran cicilan kendaraan, kartu kredit, PBB (Pajak Bumi \& Bangunan), dan lain-lain. Dengan adanya teknologi internet, pembayaran tagihan menjadi lebih mudah dilakukan. Demikian juga dengan transaksi perbankan, hampir semua transaksi perbankan sudah bermigrasi menjadi transaksi digital sehingga dapat dilakukan kapanpun dan dimanapun.

Menurut Bank Indonesia (BI), uang elektronik didefinisikan sebagai alat pembayaran dalam bentuk elektronik dimana nilai uangnya disimpan dalam media elektronik tertentu. Pengguna harus menyetorkan uangnya terlebih dahulu kepada penerbit dan disimpan dalam media elektronik sebelum digunakan untuk keperluan transaksi. Penggunaan uang elektronik merupakan alat pembayaran yang inovatif sehingga transaksi ekonomi menjadi lebih mudah, cepat, dan aman. Cukup melalui smartphone yang terhubung internet, semua transaksi dapat dilakukan dengan cepat. Menurut hasil riset yang dilakukan oleh Ipsos Indonesia (perusahaan riset pemasaran independen) menyatakan bahwa terdapat tiga motivasi besar mengapa masyarakat Indonesia beralih ke dompet digital yaitu; rasa aman, menyenangkan, dan dapat memperkaya hidup dengan sesuatu yang baru. Dapat disimpulkan bahwa transaksi digital sudah merupakan gaya hidup (life style) sebagai dampak dari perkembangan teknologi internet yang semakin canggih. Konsumen menginginkan pembayaran nontunai yang aman, nyaman, mudah, efisien, dan lengkap sehingga dapat digunakan untuk semua transaksi.

\section{Dampak Positif Transaksi Digital}

Secara singkat keuntungan atau manfaat dari transaksi digital adalah sebagai berikut:

\section{Aman}

Situs e-banking dilengkapi dengan teknologi pengaman transaksi Secure Socket Layer (SSL) dan protokol Hypertext Transfer Protocol Secure (HTTPS) sehingga transaksi yang dilakukan dijamin keamanannya.

\section{Cepat}

Transaksi digital menggunakan koneksi internet sehingga dapat diproses dengan cepat walaupun jaraknya ribuan kilometer.

\section{Mudah}

Aplikasi sistem pembayaran transaksi pada umumnya dibuat sangat sederhana (user friendly) sehingga mudah dalam penggunaannya[7].

\section{Hemat Waktu}

Transaksi dapat dilakukan kapanpun dan dimanapun sehingga dapat menghemat waktu.

\section{Mudah Dikontrol}

Transaksi digital lebih mudah dikontrol karena semuanya tercatat secara detail dalam sistem.

\section{Meminimalisir Penggunaan Uang} Tunai

Transaksi digital dapat mengurangi risiko kehilangan uang tunai karena semua transaksi cashless (nontunai) dan dapat 
dilakukan via Smartphone. Dana dalam rekening tetap aman karena hanya pemilik akun yang mengetahui nomor PIN (Personal Identification Number) dari rekening tersebut. Nomor PIN ini bersifat rahasia dan tidak boleh dibocorkan kepada siapapun termasuk pihak perbankan.

\section{Banyak Promo Menarik}

Konsumen dapat memilih aplikasi transaksi digital yang memberikan banyak promo dan diskon sehingga dapat memperoleh barang yang diinginkan dengan harga lebih murah.

\section{Dampak Negatif Transaksi Digital}

Selain manfaat/keuntungan, transaksi digital juga memiliki sisi negatif seperti berikut ini:

\section{Lebih Boros}

Banyaknya tawaran dan diskon menarik dari aplikasi-aplikasi e-commerce membuat konsumen tergiur dan tidak memperdulikan anggaran yang dimilikinya untuk berbelanja.

\section{Ancaman Cyber Crime}

Cyber Crime adalah semua tindakan ilegal yang dilakukan melalui jaringan komputer dan internet untuk mendapatkan keuntungan dengan merugikan pihak lain. Secanggih apapun sistem keamanan transaksi digital, selalu ada celah bagi pelaku kejahatan internet. Mereka dapat meretas aplikasi dengan cara skimming (menggandakan data pemilik rekening), lalu bertransaksi seolah-olah sebagai pemilik rekening. Untuk itu jangan pernah menginformasikan nomor PIN, Password,
Token, dan 3 nomor digit di belakang kartu kredit kepada pihak manapun.

\section{Kartu (Debit/Kredit) Hilang}

Salah satu transaksi nontunai adalah dengan menggunakan kartu kredit atau debit. Kartu-kartu tersebut berpotensi hilang jika tidak disimpan dengan baik. Sebenarnya kartu tetap aman walaupun hilang selama tidak ada yang mengetahui PIN transaksi dari kartu-kartu tersebut.

\section{Berpotensi Memiliki Utang}

Banyak aplikasi e-commerce memberikan kemudahan pembayaran dengan cara dicicil. Kemudahan bertransaksi online dan banyaknya promo serta diskon dapat membuat konsumen terlena untuk melakukan transaksi digital terus-menerus tanpa memperdulikan lagi kemampuan keuangannya.

\section{Aplikasi Digital Perlu Dipelajari}

Bagi generasi milenial dan konsumen yang selalu update perkembangan informasi teknologi, tidaklah sulit memahami aplikasi-aplikasi digital, tetapi bagi konsumen yang sudah berusia lanjut dan tidak begitu paham dengan teknologi, akan menemui kesulitan ketika bertransaksi. Mereka akhirnya lebih memilih transaksi offline daripada online.

Selain dampak positif dan negatif di atas, transaksi digital secara umum sangat berdampak pada perekonomian Indonesia seperti berikut ini:

\section{Dapat Menimbulkan Inflasi}

Secara umum inflasi dapat terjadi karena permintaan, bertambahnya uang yang beredar, kenaikan biaya produksi, inflasi 
campuran, dan struktural ekonomi yang kaku. Namun penggunaan e-money walaupun tidak dapat menyebabkan inflasi secara langsung, tetapi jika penggunaannya tidak sesuai dengan jumlah fisik uang tunai maka inflasi dapat terjadi.

\section{Mempercepat Perputaran Uang}

Uang elektronik dapat meningkatkan perputaran uang karena transaksi dapat dilakukan dengan cepat dan mudah sehingga jumlah transaksi dapat meningkat dengan tajam hanya dalam hitungan detik.

\section{Menurunkan Permintaan Uang Tunai}

Tingginya transaksi digital menurunkan permintaan terhadap uang tunai. Walaupun permintaan ini menurun, tetapi transaksi ekonomi terus berjalan bahkan lebih cepat[8].

\section{Pertumbuhan Ekonomi}

Asfia Murni, dalam bukunya Ekonomi Makro, menjelaskan bahwa pertumbuhan ekonomi digunakan untuk menggambarkan terjadinya kemajuan atau perkembangan ekonomi dalam suatu negara. Sedangkan pembangunan ekonomi merupakan suatu proses multidimensional yang mencakup berbagai perubahan mendasar atas struktur sosialekonomi, sikap-sikap masyarakat, dan institusiinstitusi nasional, disamping tetap mengejar akselerasi pertumbuhan ekonomi[9]. Pertumbuhan ekonomi bersifat jangka panjang dan merupakan sumber utama dalam peningkatan standar hidup ekonomi masyakarat.

Tujuan pertumbuhan ekonomi adalah untuk meningkatkan nilai PDB. Suatu negara dikatakan mengalami pertumbuhan ekonomi apabila nilai Produk Domestik Bruto (PDB) di negara tersebut meningkat.

Teori-teori tentang pertumbuhan ekonomi banyak dilahirkan oleh para ahli ekonomi dunia. Salah satunya adalah teori Pertumbuhan Ekonomi Endogen (Endogenous Economic Growth). Dalam teori Endogen, sumber daya manusia dan inovasi teknologi dianggap paling berpengaruh dalam pertumbuhan ekonomi. Indonesia berpotensi menjadi negara adidaya ekonomi karena memiliki 2 potensi tersebut. Penguatan faktor internal (endogen) berdampak secara positif pada faktor eksternal sebagai spillover[10]. Spillover adalah eksternalitas kegiatan ekonomi atau proses yang memengaruhi tetapi tidak berhubungan langsung. Misalnya efek spillover dari peningkatan perdagangan adalah pembentukan aliansi multilateral seperti dibentuknya ASEAN (Association of South East Asian Nations).

Teori lainnya tentang pertumbuhan ekonomi adalah teori Neoklasik Solow-Swan. Teori ini berpendapat bahwa terdapat 2 faktor yang berperan dalam pertumbuhan ekonomi yaitu peningkatan nilai Produk Domestik Bruto (PDB) dan pengembangan teknologi.

\section{Mengukur Pertumbuhan Ekonomi}

Badan Pusat Statistik (BPS) menjelaskan bahwa salah satu indikator penting untuk 
mengetahui pertumbuhan ekonomi suatu negara adalah data Produk Domestik Bruto (PDB), baik atas dasar berlaku maupun atas dasar harga konstan. PDB adalah jumlah nilai tambah yang dihasilkan oleh seluruh unit usaha dalam suatu negara pada suatu periode tertentu, biasanya satu tahun. PDB juga dapat diartikan jumlah nilai barang dan jasa akhir yang dihasilkan oleh seluruh unit ekonomi.

PDB Atas Dasar Harga Berlaku digunakan untuk melihat pergeseran dan struktur ekonomi karena dapat menggambarkan nilai tambah barang dan jasa yang dihitung menggunakan harga yang berlaku pada setiap tahun. Sedangkan PDB Atas Dasar Harga Konstan digunakan sebagai parameter pertumbuhan ekonomi dari tahun ke tahun karena nilai tambah barang dan jasa dihitung menggunakan harga yang berlaku pada satu tahun tertentu sebagai tahun dasar.

Produk Domestik Bruto (PDB) dapat dihitung dengan tiga pendekatan:

\section{Pendekatan Produksi}

Dalam Pendekatan Produksi, PDB dihitung dari jumlah nilai tambah atas barang dan jasa yang dihasilkan oleh berbagai unit produksi di wilayah suatu negara dalam jangka waktu tertentu (biasanya satu tahun). Unit-unit produksi dikelompokkan menjadi 9 sektor dan dirinci lagi menjadi sub-sub sektor. Salah satu sektor dalam PDB adalah Sektor Transportasi dan Komunikasi, dimana sektor ini berhubungan langsung dengan transaksi digital.

\section{Pendekatan Pendapatan}

Dalam Pendekatan Pendapatan, PDB dihitung atas jumlah balas jasa yang diterima oleh faktor-faktor produksi (gaji, sewa tanah, bunga modal, dll) yang digunakan dalam proses produksi di suatu wilayah negara dalam jangka waktu tertentu (biasanya satu tahun).

\section{Pendekatan Pengeluaran}

Dalam Pendekatan Pengeluaran, PDB dihitung dari pengeluaran 4 komponen permintaan akhir yang terdiri dari Konsumsi Rumah Tangga, Konsumsi Pemerintah, Investasi, dan Ekspor Neto.

Ketiga pendekatan PDB ini sebenarnya memiliki konsep yang sama. Jumlah pengeluaran hasilnya akan sama dengan jumlah barang dan jasa akhir yang dihasilkan, dan harus sama pula dengan jumlah pendapatan untuk faktor-faktor produksi.

Menurut N. Gregory Mankiw dalam bukunya Pengantar Ekonomi Makro, Produk Domestik Bruto (PDB) atau Gross Domestic Bruto (GDP) adalah nilai pasar dari seluruh barang dan jasa akhir yang diproduksi dalam suatu negara selama periode tertentu[11].

\section{Rumus PDB (Pendekatan Pengeluaran):}

$\mathbf{Y}=\mathbf{C}+\mathbf{G}+\mathbf{I}+\mathbf{N X}$

C: Konsumsi (Consumption)

G: Belanja Pemerintah (Government

Purchases)

I: Investasi (Investment)

NX: Ekspor Neto (Net Export)

Berikut penjelasan detail dari komponenkomponen penting dalam perhitungan PDB: 
1. Konsumsi (Consumption) adalah pengeluaran dari rumah tangga untuk membeli barang dan jasa, dengan pengecualian pada pembelian rumah baru. Komponen ini paling berpengaruh dalam PDB dan pertumbuhan ekonomi.

\section{Belanja Pemerintah (Government}

Purchases) adalah pengeluaran belanja pada barang dan jasa yang dilakukan oleh pemerintah.

3. Investasi (Investment) adalah pembelian barang dan jasa yang akan digunakan untuk memproduksi lebih banyak barang dan jasa, termasuk pembelian rumah baru.

4. Ekspor Neto (Net Export) adalah pembelian luar negeri terhadap barang dan jasa yang diproduksi di dalam negeri (ekspor) dikurangi pembelian dalam negeri terhadap barang dan jasa yang diproduksi di luar negeri (impor). Kata Neto pada Ekspor Neto mengacu pada impor yang telah dikurangi dengan ekspor.

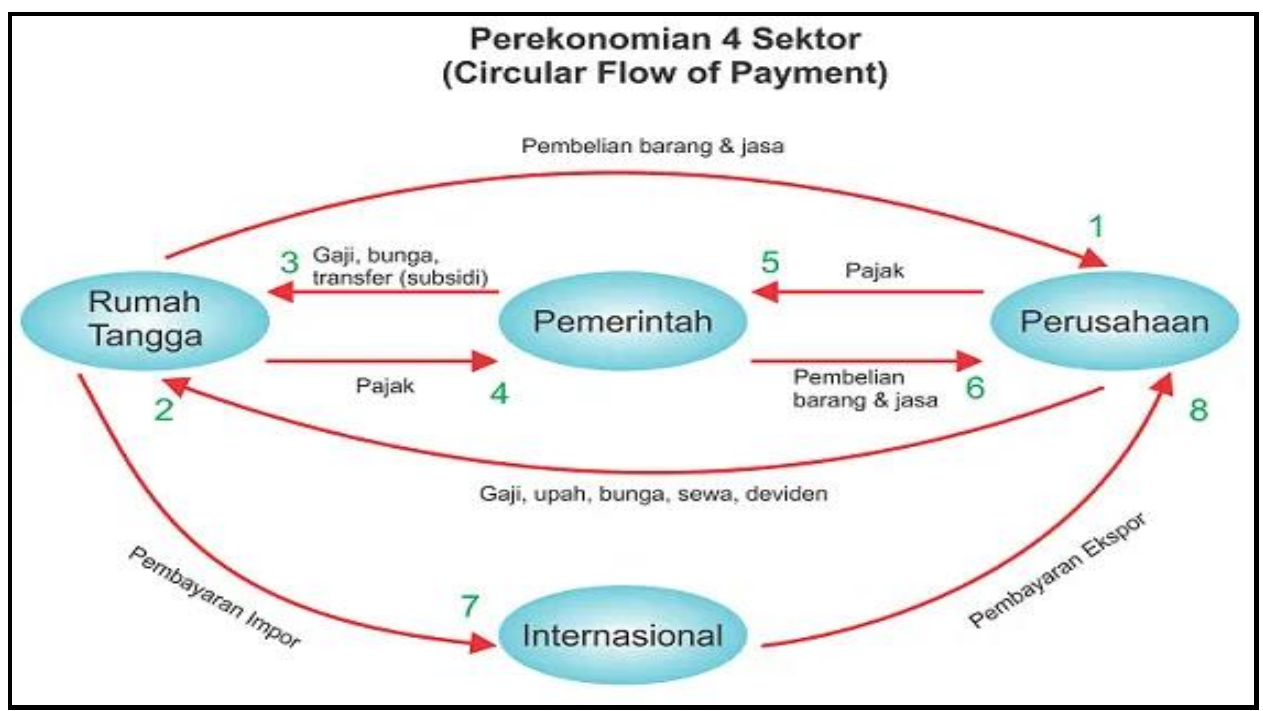

Gambar 1: Perekonomian 4 Sektor

(Sumber: Studiekonomi.com)

\section{Pertumbuhan Ekonomi Indonesia}

Pertumbuhan ekonomi Indonesia mengalami hambatan luar biasa selama dua tahun terakhir (2020 - 2021) karena pandemi Covid-19. Selain mengakibatkan krisis kesehatan, pandemi sangat berdampak pada pertumbuhan ekonomi sehingga mengalami perlambatan. Pada sisi lain, jumlah uang elektronik yang beredar justru meningkat pesat pada saat pandemi Covid-19. Kemajuan tekonologi digital telah membantu ekonomi Indonesia tetap berjalan pada saat pandemi Covid-19. Munculnya uang elektronik (e-money) sebagai pengganti uang tunai memudahkan masyarakat bertransaksi bisnis dan perbankan secara digital.

Nefo Indra Rizar, dalam artikelnya yang berjudul "Pertumbuhan Ekonomi selama Pandemi Covid-19" menjelaskan bahwa berdasarkan transaksi ekonomi digital terlihat nilai transaksi e-commerce mengalami 
kenaikan dari tahun ke tahun. Pada tahun 2014 nilai transaksi e-commerce sebesar 25,08 triliun, kemudian naik menjadi 144,4 triliun pada tahun 2018. Jumlah penggunaan uang elektronik untuk kebutuhan transaksi naik dengan sangat tinggi pada tahun 2019 yaitu dengan volume sebesar 5,23 milyar atau dengan nominal sebesar 145, 16 triliun[12].

Sebenarnya Indonesia sudah memulai langkah awal ekonomi digital. Pada tahun 2014, Pemerintah Indonesia sudah merancang $E$ commerce Roadmap untuk pengembangan industri e-commerce lokal. Ditemukan terdapat enam hambatan dalam pertumbuhan $e$ commerce di Indonesia yaitu masalah Pendanaan, Perpajakan, Perlindungan Konsumen, Infrastruktur Komunikasi, Logistik, dan Edukasi dan Sumber Daya Manusia.

Pada tahun 2022, Indonesia akan menjadi tuan rumah pertemuan G20. G20 adalah sebuah forum diskusi menteri keuangan dan gubernur bank sentral dari 20 negara perekonomian terbesar di dunia. G20 berperan sebagai sarana diskusi yang krusial, terutama dalam bidang ekonomi dan keuangan. Pada pertemuan G20 tersebut, Pemerintah Indonesia akan mengusung tema "Recover Together, Recover Stronger". Tema ini diambil dengan mempertimbangkan krisis kesehatan yang sedang terjadi saat ini dimana membutuhkan usaha kerjasama dan koordinasi pada tingkat internasional.

\section{METODE PENELITIAN}

Dalam penelitian ini, Penulis menggunakan metode Analisis Deskriptif. Menurut Arikunto (2019) Penelitian Deskriptif adalah penelitian untuk menyelidiki suatu kondisi, keadaan, atau peristiwa, kemudian hasilnya akan dipaparkan dalam bentuk laporan penelitian.

Untuk menganalisis dampak peningkatan jumlah uang elektronik (e-money) yang beredar terhadap pertumbuhan ekonomi Indonesia pada masa pandemi Covid-19, Penulis menggunakan data PDB Harga Konstan dan Jumlah Uang Elektronik (e-Money) Beredar. Data yang diambil adalah data dua tahun terakhir (2020 2021) dimana pandemi Covid-19 terjadi.

Semua data diolah dan dianalisis untuk mengetahui apakah peningkatan jumlah uang elektronik (e-money) yang beredar berkolerasi positif terhadap pertumbuhan ekonomi Indonesia atau tidak. Analisis dilakukan dengan cara membandingkan persentase pertumbuhan dari setiap data variabel yang diuji.

Berikut data Triwulanan Produk Domestik Bruto (PDB) Atas Dasar Harga Konstan Menurut Pengeluaran Tahun 2019, Tahun 2020, dan Tahun 2021 (Juli)[13]: 
Tabel 1: Data PDB Tahun 2019

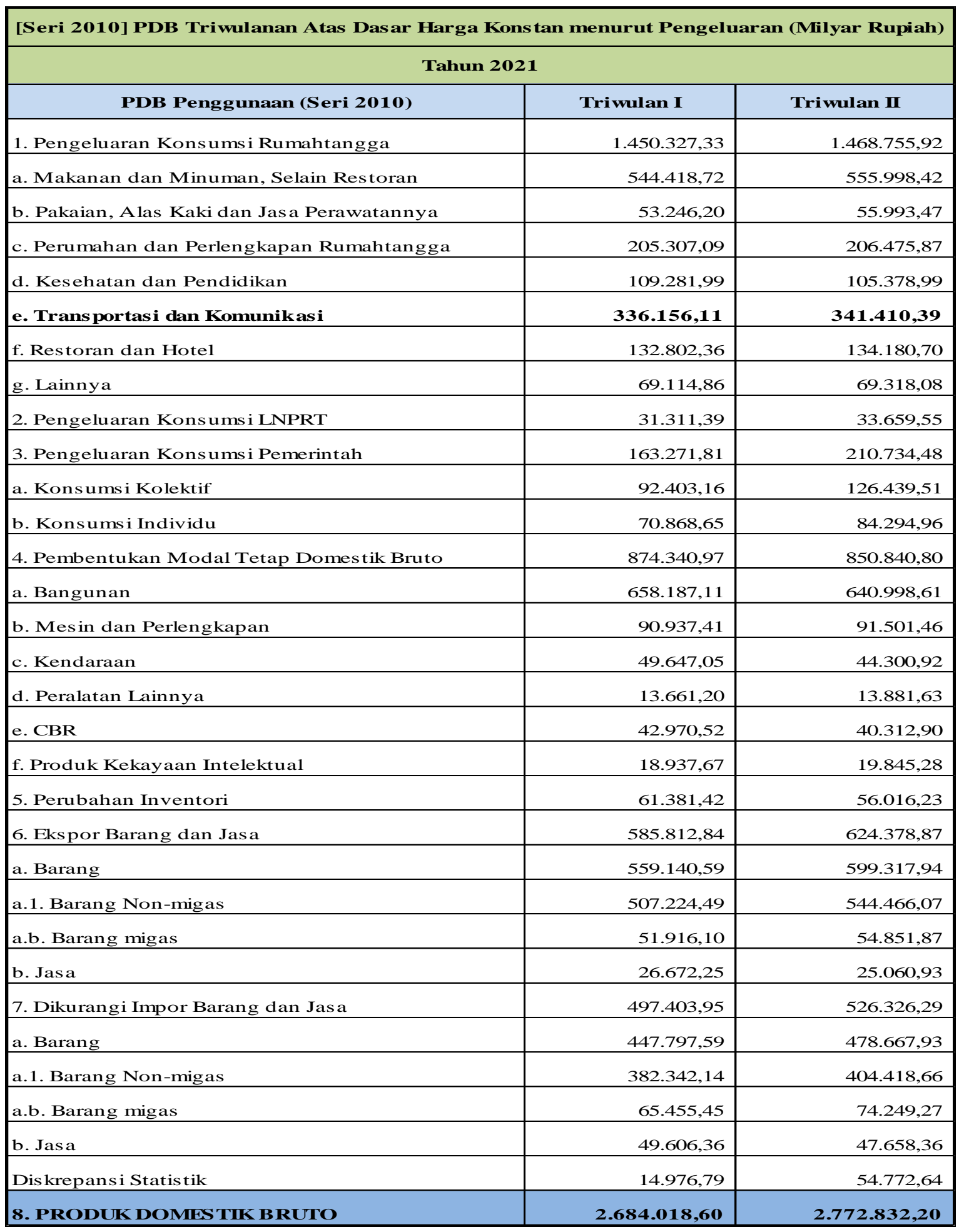

Sumber: Badan Pusat Statistik (BPS) 
Tabel 2: Data PDB Tahun 2020

\begin{tabular}{|c|c|c|c|c|c|}
\hline \multicolumn{6}{|c|}{ [Seri 2010] PDB Triwulanan Atas Dasar Harga Konstan menurut Pengeluaran (Milyar Rupiah) } \\
\hline \multicolumn{6}{|c|}{ Tahun 2020} \\
\hline PDB Penggunaan (Seri 2010) & Triwulan I & Triwulan II & Triwulan III & Triwulan IV & Tahunan \\
\hline 1. Pengeluaran Konsumsi Rumah Tangga & $1.483 .329,23$ & $1.386 .534,81$ & $1.451 .587,57$ & $1.458 .766,52$ & $5.780 .218,14$ \\
\hline a. Makanan dan Minuman, Selain Restoran & $557.270,91$ & $535.191,06$ & $552.849,35$ & $544.924,32$ & $2.190 .235,64$ \\
\hline b. Pakaian, Alas Kaki dan Jasa Perawatannya & $54.724,83$ & $55.073,27$ & $55.398,00$ & $55.993,24$ & $221.189,33$ \\
\hline c. Perumahan dan Perlengkapan Rumahtangga & $202.687,64$ & $202.272,48$ & $204.200,69$ & $205.377,48$ & $814.538,29$ \\
\hline d. Kesehatan dan Pendidikan & $108.951,29$ & $104.126,73$ & $109.472,24$ & $107.984,43$ & $430.534,69$ \\
\hline e. Trans portasi dan Komunikasi & 351.048,99 & $308.723,14$ & $333.097,95$ & $340.754,25$ & $1.333 .624,33$ \\
\hline f. Restoran dan Hotel & $138.555,07$ & $114.893,60$ & $127.901,42$ & $134.856,23$ & $516.206,32$ \\
\hline g. Lainnya & $70.090,50$ & $66.254,54$ & $68.667,92$ & $68.876,58$ & $273.889,54$ \\
\hline 2. Pengeluaran Konsumsi LNPRT & $32.625,95$ & $32.327,42$ & $32.584,34$ & $32.655,61$ & $130.193,32$ \\
\hline 3. Pengeluaran Konsumsi Pemerintah & $159.531,45$ & $195.012,93$ & $228.050,20$ & $289.963,74$ & $872.558,31$ \\
\hline a. Konsumsi Kolektif & $96.821,53$ & $116.105,39$ & $133.726,00$ & $180.035,17$ & $526.688,09$ \\
\hline b. Konsumsi Individu & $62.709,92$ & $78.907,53$ & $94.324,19$ & $109.928,57$ & $345.870,22$ \\
\hline 4. Pembentukan Modal Tetap Domestik Bruto & $876.315,84$ & $791.204,43$ & $858.097,83$ & $894.086,10$ & $3.419 .704,20$ \\
\hline a. Bangunan & $663.115,71$ & $614.245,37$ & $641.327,25$ & $666.934,64$ & $2.585 .622,97$ \\
\hline b. Mesin dan Perlengkapan & $87.877,92$ & $76.857,55$ & $82.968,61$ & $94.548,98$ & $342.253,06$ \\
\hline c. Kendaraan & $48.635,15$ & $31.142,97$ & $41.644,52$ & $46.861,89$ & $168.284,52$ \\
\hline d. Peralatan Lainnya & $14.361,45$ & $10.155,90$ & $12.870,61$ & $14.591,21$ & $51.979,17$ \\
\hline e. $\mathrm{CBR}$ & $43.485,00$ & $39.931,00$ & $58.146,00$ & $54.378,49$ & $195.940,49$ \\
\hline f. Produk Kekayaan Intelektual & $18.840,62$ & $18.871,64$ & $21.140,85$ & $16.770,88$ & $75.623,98$ \\
\hline 5. Perubahan Inventori & $50.546,33$ & $66.004,87$ & $7.509,07$ & $57.708,00$ & $51.334,13$ \\
\hline 6. Eks por Barang dan Jasa & $547.350,28$ & $473.792,21$ & $529.063,92$ & $541.831,54$ & $2.092 .037,95$ \\
\hline a. Barang & $499.538,17$ & $449.974,72$ & $502.156,14$ & $512.867,69$ & $1.964 .536,72$ \\
\hline a.1. Barang Non-migas & $454.382,61$ & $406.377,70$ & $458.491,71$ & $466.271,61$ & $1.785 .523,63$ \\
\hline a.b. Barang migas & $45.155,56$ & $43.597,02$ & $43.664,43$ & $46.596,09$ & $179.013,09$ \\
\hline b. Jasa & $47.812,11$ & $23.817,49$ & $26.907,78$ & $28.963,85$ & $127.501,23$ \\
\hline 7. Dikurangi Impor Barang dan Jasa & $471.650,13$ & $401.108,77$ & $401.050,41$ & $466.357,02$ & $1.740 .166,33$ \\
\hline a. Barang & $410.946,44$ & $364.774,97$ & $361.923,71$ & $414.108,50$ & $1.551 .753,62$ \\
\hline a.1. Barang Non-migas & $342.397,11$ & $312.005,05$ & $309.911,19$ & $356.824,70$ & $1.321 .138,05$ \\
\hline a.b. Barang migas & $68.549,33$ & $52.769,92$ & $52.012,52$ & $57.283,80$ & $230.615,57$ \\
\hline b. Jasa & $60.703,69$ & $36.333,80$ & $39.126,70$ & $52.248,52$ & $188.412,71$ \\
\hline Diskrepansi Statis tik & $25.100,05$ & $46.050,20$ & $29.654,12$ & $15.758,61$ & $116.562,98$ \\
\hline 8. PRODUK DOMES TIK BRUTO & $2.703 .149,00$ & $2.589 .818,10$ & $2.720 .478,50$ & $2.708 .997,10$ & $10.722 .442,70$ \\
\hline
\end{tabular}

Sumber: Badan Pusat Statistik (BPS) 
Tabel 3: Data PDB Tahun 2021

\begin{tabular}{|c|c|c|}
\hline \multicolumn{3}{|c|}{ [Seri 2010] PDB Triwulanan Atas Dasar Harga Konstan menurut Pengeluaran (Milyar Rupiah) } \\
\hline \multicolumn{3}{|c|}{ Tahun 2021} \\
\hline PDB Penggunaan (Seri 2010 ) & Triwulan I & Triwulan II \\
\hline 1. Pengeluaran Konsumsi Rumahtangga & $1.450 .327,33$ & $1.468 .755,92$ \\
\hline a. Makanan dan Minuman, Selain Restoran & $544.418,72$ & $555.998,42$ \\
\hline b. Pakaian, Alas Kaki dan Jasa Perawatannya & $53.246,20$ & $55.993,47$ \\
\hline c. Perumahan dan Perlengkapan Rumahtangga & 205.307,09 & $206.475,87$ \\
\hline d. Kesehatan dan Pendidikan & $109.281,99$ & $105.378,99$ \\
\hline e. Trans portasi dan Komunikasi & $336.156,11$ & 341.410,39 \\
\hline f. Restoran dan Hotel & $132.802,36$ & $134.180,70$ \\
\hline g. Lainnya & $69.114,86$ & $69.318,08$ \\
\hline 2. Pengeluaran Konsumsi LNPRT & $31.311,39$ & $33.659,55$ \\
\hline 3. Pengeluaran Konsumsi Pemerintah & $163.271,81$ & $210.734,48$ \\
\hline a. Konsumsi Kolektif & $92.403,16$ & $126.439,51$ \\
\hline b. Konsums i Individu & $70.868,65$ & $84.294,96$ \\
\hline 4. Pembentukan Modal Tetap Domestik Bruto & $874.340,97$ & $850.840,80$ \\
\hline a. Bangunan & $658.187,11$ & $640.998,61$ \\
\hline b. Mesin dan Perlengkapan & $90.937,41$ & $91.501,46$ \\
\hline c. Kendaraan & $49.647,05$ & $44.300,92$ \\
\hline d. Peralatan Lainnya & $13.661,20$ & $13.881,63$ \\
\hline e. CBR & $42.970,52$ & $40.312,90$ \\
\hline f. Produk Kekayaan Intelektual & $18.937,67$ & $19.845,28$ \\
\hline 5. Perubahan Inventori & $61.381,42$ & $56.016,23$ \\
\hline 6. Ekspor Barang dan Jasa & $585.812,84$ & $624.378,87$ \\
\hline a. Barang & $559.140,59$ & $599.317,94$ \\
\hline a.1. Barang Non-migas & $507.224,49$ & $544.466,07$ \\
\hline a.b. Barang migas & $51.916,10$ & $54.851,87$ \\
\hline b. Jasa & $26.672,25$ & $25.060,93$ \\
\hline 7. Dikurangi Impor Barang dan Jas a & $497.403,95$ & $526.326,29$ \\
\hline a. Barang & $447.797,59$ & $478.667,93$ \\
\hline a.1. Barang Non-migas & $382.342,14$ & $404.418,66$ \\
\hline a.b. Barang migas & $65.455,45$ & $74.249,27$ \\
\hline b. Jasa & $49.606,36$ & $47.658,36$ \\
\hline Dis krepansi Statis tik & $14.976,79$ & $54.772,64$ \\
\hline 8. PRODUK DOMIES TIK B RUTO & $2.684 .018,60$ & $2.772 .832,20$ \\
\hline
\end{tabular}

Sumber: Badan Pusat Statistik (BPS)

Tabel 4 : Pertumbuhan PDB Tahun 2020 - 2021 (qtq)

\begin{tabular}{|c|c|c|c|c|c|c|c|}
\hline & $\frac{2019}{\text { Triwulan IV }}$ & \multicolumn{4}{|c|}{2020} & \multicolumn{2}{|c|}{2021} \\
\hline PDB ATAS HARGA KONSTAN & $2.769 .787,50$ & 2.703.149,00 & $2.589 .818,10$ & $2.720 .478,00$ & 2.708.997,10 & $2.684 .018,60$ & $2.772 .832,20$ \\
\hline NILAI PERTUMBUHAN PDB (\%) & & $-2,41$ & $-4,19$ & 5,05 & $-0,42$ & $-0,92$ & 3,31 \\
\hline
\end{tabular}


Pandemi Covid-19 telah memberikan dampak yang sangat berat terhadap kondisi perekonomian Indonesia. Selama tahun 2020, PDB mengalami kontraksi selama 3 kuartal yaitu Triwulan I sebesar 2,41\% (qtq), dan pada Triwulan II kontraksi semakin dalam yaitu sebesar -4,19\% (qtq). Pada kuartal III perekonomian Indonesia mulai bangkit, tumbuh sebesar 5,05\% (qtq). Namun pada Kuartal IV tahun 2020, nilai PDB kembali terkontraksi sebesar $-0,42 \%(q t q)$.

Pertumbuhan ekonomi Indonesia pada Triwulan II-2021 naik sebesar 3,31\% dibandingkan dengan Triwulan I-2021 (qtq). Pertumbuhan terjadi pada hampir semua lapangan usaha.

Tabel 5 : Pertumbuhan PDB Triwulan II-2020 vs Triwulan II-2021

\begin{tabular}{|c|c|c|c|c|}
\hline TAHUN & \multicolumn{2}{|c|}{2020} & \multicolumn{2}{c|}{2021} \\
\hline TRIWULAN & Triwulan I & Triwulan II & Triwulan I & Triwulan II (Juli) \\
\hline PDB ATAS HARGA KONSTAN & $\mathbf{2 . 7 0 3 . 1 4 9 , 0 0}$ & $\mathbf{2 . 5 8 9 . 8 1 8 , 1 0}$ & $\mathbf{2 . 6 8 4 . 0 1 8 , 6 0}$ & $\mathbf{2 . 7 7 2 . 8 3 2 , 2 0}$ \\
\hline NILAI PERTUMBUHAN PDB $(\%)$ & & & $-\mathbf{0 , 7 1}$ & 7,07 \\
\hline
\end{tabular}

Jika dilihat secara year on year, nilai Produk Domestik Bruto (PDB) mengalami pertumbuhan. Hal ini dapat dilihat pada Triwulan II-2021 nilai PDB mencapai Rp2.772,8 triliun, sedangkan pada Triwulan II2020 hanya mencapai Rp2.589,8 triliun (tumbuh 7,07\%).
Bank Indonesia (BI) melaporkan bahwa jumlah uang elektronik yang beredar (e-money) terus mengalami peningkatan sejak tahun 2019 hingga tahun 2021 (Juli) seperti terlihat dalam tabel dan grafik di bawah ini:

Tabel 6 : Jumlah Uang Elektronik Beredar Per Triwulan (2019 - 2021)

\begin{tabular}{|c|c|c|c|c|c|c|c|}
\hline & 2019 & \multicolumn{4}{|c|}{2020} & \multicolumn{2}{|c|}{2021} \\
\hline & Triwulan IV & Triwulan I & Triwulan II & Triwulan III & Triwulan IV & Triwulan I & Triwulan II (Juli) \\
\hline JUMLAH UANG ELEKTRONIK BEREDAR & 292.299 .320 & 330.391 .364 & 353.587 .670 & 393.904.001 & 432.281.380 & 470.811 .351 & 511.254 .525 \\
\hline PERTUMBUHAN UANG ELEKTRONIK (\%) & & 13,03 & 7,02 & 11,40 & $\mathbf{9 , 7 4}$ & 8,91 & 8,59 \\
\hline
\end{tabular}

Tabel 7: Jumlah Uang Elektronik Beredar Tahun 2019 - 2021 (Juli)

\begin{tabular}{|r|r|r|}
\hline Tahun 2019 & \multicolumn{1}{|c|}{ Tahun 2020 } & Tahun 2021 (Juli) \\
\hline 292.299 .320 & 432.281 .380 & 495.280 .424 \\
\hline
\end{tabular}

Sumber: Bank Indonesia (BI) 


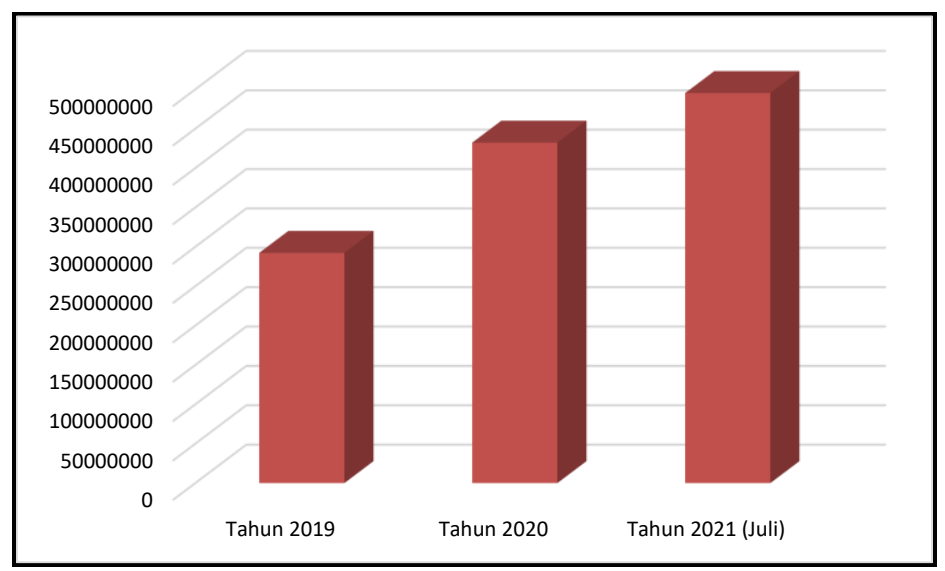

Gambar 2 : Grafik Jumlah Uang Elektronik Beredar (Sumber: BI)

Jika dianalisis pertumbuhan data Produk dan tahun 2021, maka hasilnya adalah sebagai Domestik Bruto (PDB) dan Jumlah Uang berikut:

Elektronik (e-money) Beredar dari tahun 2020

Tabel 8 : PDB Harga Konstan vs Jumlah Uang Elektronik Beredar

(Per Triwulan 2020 - 2021)

\begin{tabular}{|c|c|c|c|c|c|c|c|}
\hline & 2019 & \multicolumn{4}{|c|}{2020} & \multicolumn{2}{|c|}{2021} \\
\hline & Triwulan IV & Triwulan I & Triwulan II & Triwulan III & Triwulan IV & Triwulan I & Triwulan II (Juli) \\
\hline PDB ATAS HARGA KONSTAN & $\mathbf{2 . 7 6 9 . 7 8 7 , 5 0}$ & $\mathbf{2 . 7 0 3 . 1 4 9 , 0 0}$ & $\mathbf{2 . 5 8 9 . 8 1 8 , 1 0}$ & $\mathbf{2 . 7 2 0 . 4 7 8 , 0 0}$ & $\mathbf{2 . 7 0 8 . 9 9 7 , 1 0}$ & $\mathbf{2 . 6 8 4 . 0 1 8 , 6 0}$ & $\mathbf{2 . 7 7 2 . 8 3 2 , 2 0}$ \\
\hline NILAI PERTUMBUHAN PDB $(\%)$ & & $-2,41$ & $-4,19$ & $\mathbf{5 , 0 5}$ & $-\mathbf{0 , 4 2}$ & $-\mathbf{0 , 9 2}$ & $\mathbf{3 , 3 1}$ \\
\hline JUMLAH UANG ELEKTRONIK BEREDAR & $\mathbf{2 9 2 . 2 9 9 . 3 2 0}$ & $\mathbf{3 3 0 . 3 9 1 . 3 6 4}$ & $\mathbf{3 5 3 . 5 8 7 . 6 7 0}$ & $\mathbf{3 9 3 . 9 0 4 . 0 0 1}$ & $\mathbf{4 3 2 . 2 8 1 . 3 8 0}$ & $\mathbf{4 7 0 . 8 1 1 . 3 5 1}$ & $\mathbf{5 1 1 . 2 5 4 . 5 2 5}$ \\
\hline PERTUMBUHAN UANG ELEKTRONIK $(\%)$ & & $\mathbf{1 3 , 0 3}$ & $\mathbf{7 , 0 2}$ & $\mathbf{1 1 , 4 0}$ & $\mathbf{9 , 7 4}$ & $\mathbf{8 , 9 1}$ & $\mathbf{8 , 5 9}$ \\
\hline
\end{tabular}

Sumber: Data primer yang sudah diolah, 2020 - 2021

Pertumbuhan uang elektronik (e-money) yang beredar dapat diperbandingkan juga dengan data pada Sektor Pengangkutan (Transportasi) dan Komunikasi pada PDB. Uang elektronik sebagai alat pembayaran transaksi digital tentunya membutuhkan koneksi internet.
Pembelian kuota internet masuk dalam Sektor Komunikasi pada PDB. Jika diperbandingkan antara Triwulan II-2020 dan Triwulan II-2021 (Juli), Sektor Transportasi dan Komunikasi mengalami pertumbuhan sebesar 10,59\%. Hal ini dapat dilihat pada tabel berikut ini:

Tabel 9: Pertumbuhan Uang Elektronik Triwulan II-2020 dan Triwulan II-2021

\begin{tabular}{|c|c|c|c|c|}
\hline TAHUN & 2020 & \multicolumn{2}{c|}{2021} \\
\hline TRIWULAN & Triwulan I & Triwulan II & Triwulan I & Triwulan II (Juli) \\
\hline SEKTOR TRANSPORTASI \& KOMUNIKASI & $351.048,99$ & $308.723,14$ & $336.156,11$ & $341.410,39$ \\
\hline NILAI PERTUMBUHAN (\%) & & & $-4,24$ & 10,59 \\
\hline
\end{tabular}


HASIL DAN PEMBAHASAN

Hasil

Setelah dianalisis antara data Pertumbuhan pertumbuhan Jumlah Uang Elektronik Beredar, maka hasil analisisnya dapat digambarkan dalam kurva seperti berikut ini:

PDB atas dasar Harga Konstan dan

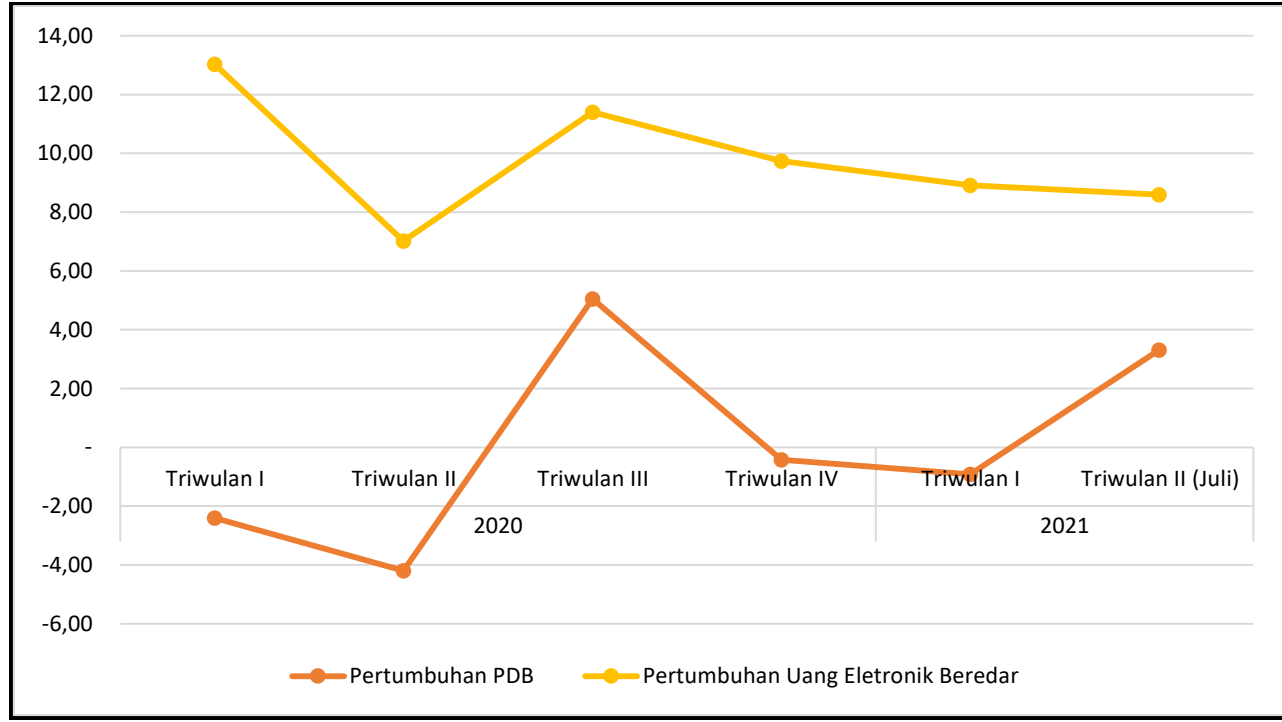

Gambar 3 : Kurva Pertumbuhan PDB dan Pertumbuhan Jumlah Uang Elektronik Beredar

\section{PEMBAHASAN}

Triwulan I (Januari - Maret 2020)

Nilai PDB pada Triwulan I Tahun 2020 mengalami kontraksi sebesar $-2,41 \%$. Hal ini berbanding terbalik dengan jumlah uang elektronik beredar yang mengalami pertumbuhan sebesar $13,03 \%$. Pada akhir Triwulan I-2020, Virus Corona baru saja diumumkan masuk ke Indonesia. Hal ini berdampak pada semua transaksi bisnis dan perbankan. Pada saat itu hampir semua lini bisnis mengalami penurunan, dan semua transaksi mulai dialihkan ke online.

\section{Triwulan II (April - Juni 2020)}

Nilai PDB pada Triwulan II-2020 kembali mengalami kontraksi yang semakin dalam hingga mencapai $-4,19 \%$. Pemerintah mengumumkan secara resmi bahwa Indonesia mengalami resesi ekonomi karena nilai PDB berturut-turut negatif selama dua kuartal dalam tahun yang sama[15].

Pada Triwulan II-2020, kasus Covid-19 semakin meningkat. Untuk mencegah penyebaran yang semakin meluas, ruang gerak masyarakat mulai dibatasi sehingga berpengaruh terhadap kegiatan bisnis. Pada sisi lain, semua transaksi bisnis dan perbankan mulai terbiasa online. Hal ini terlihat pada pertumbuhan jumlah uang elektronik beredar yang mengalami peningkatan sebesar 7,02\%. Memang pertumbuhannya tidak sebesar pada Triwulan I, tetapi jumlah instrumennya transaksinya terus bertambah.

\section{Triwulan III (Juli - September 2020)}

Setelah ekonomi mengalami krisis pada dua kuartal berturut-turut, PDB pada Triwulan III2020 mulai tumbuh kembali sebesar 5,05\%. 
Hal ini merupakan sebuah prestasi ditengah semakin meningkatnya kasus Covid-19 di Indonesia. Uang elektronik beredar pun mengalami pertumbuhan sebesar $11,40 \%$.

\section{Triwulan IV (Oktober - Desember 2020)}

Kondisi perekonomian Indonesia ternyata belum stabil. Setelah mengalami pertumbuhan positif pada Triwulan III-2020, nilai PDB kembali terkontraksi $-0,42 \%$. Kenaikan jumlah uang elektronik sebesar 9,74\% ternyata tidak diikuti oleh kenaikan PDB. Hal ini merupakan suatu kewajaran karena hampir semua bisnis mulai mengalami kelesuan akibat dampak pandemi Covid-19. Hanya bisnis-bisnis yang vital seperti alat kesehatan, bahan makanan pokok, dan alat medis yang masih berjalan normal.

\section{Triwulan I (Januari - Maret 2021)}

Siklus ekonomi yang sama pada Triwulan I dan II tahun 2020 kembali terjadi pada Triwulan I2021. Nilai PDB terkontraksi $-0,92 \%$. Sementara itu jumlah peredaran uang elektronik terus mengalami peningkatan sebesar $8,91 \%$. Di tengah keterpurukan ekonomi, masyarakat mulai terbiasa bertransaksi online, Cashless Society semakin tumbuh subur.

\section{Triwulan II (April - Juli 2021)}

Setelah terkontraksi pada dua kuartal sebelumnya, perekonomian Indonesia kembali bangkit. Pada Triwulan II-2021 PDB naik sebesar $3,31 \% \quad(q t q)$ dan jumlah uang elektronik yang beredar pun naik sebesar 8,59\%. Pada Triwulan II ini, ekonomi Indonesia memasuki zona ekpansif yaitu bangkit dari keterpurukan. Kasus Covid-19 sudah menurun tajam dan pemerintah gencar melakukan vaksin terhadap seluruh masyarakat Indonesia. Tingkat kepercayaan masyarakat mulai tumbuh, dunia bisnis mulai bangkit kembali, dan Indonesia bersiap menjadi negara adidaya dalam ekonomi digital[16].

\section{KESIMPULAN}

Pandemi Covid-19 menyebabkan kinerja sektor-sektor dalam negeri Indonesia menurun. Diberlakukannya beberapa kebijakan dalam hal pengetatan dan pembatasan kegiatan selama pandemi Covid-19 membuat kegiatan di berbagai sektor menjadi terhambat. Sektor Transportasi dan Komunikasi, serta Sektor Jasa Kesehatan dan Sosial adalah sektor-sektor yang masih mampu bertahan di tengah pandemi Covid-19.

Akibat pandemi Covid-19, banyak usaha mengalami kebangkrutan dan akhirnya tutup beroperasi. Hal ini tentunya menyebabkan adanya peningkatan pengangguran. Dari sisi penggunaan, menurunnya konsumsi masyarakat serta kinerja ekspor yang terganggu, menghambat tumbuhnya perekonomian nasional. Berbagai upaya dan kebijakan dilakukan pemerintah untuk menanggulangi dampak pandemi Covid-19 agar tidak semakin dalam, salah satu diantaranya adalah Program Pemulihan Ekonomi Nasional (PEN).

Pada saat pandemi Covid-19, transaksi ekonomi dan keuangan digital justru meningkat pesat sejalan dengan penggunaan platform dan instrumen digital di masa pandemi. 
Meningkatnya transaksi digital tersebut menunjukkan tingginya konsumsi sehingga dapat menaikkan pertumbuhan ekonomi. Pertumbuhan Sektor Transportasi dan Komunikasi dalam PDB didukung oleh penggunaan internet di masa pandemi Covid-19 yang mengalami peningkatan signifikan karena hampir semua aktivitas dilakukan secara daring.

Dari hasil analisis terhadap nilai pertumbuhan PDB dan Jumlah peredaran uang elektronik ( $e$ money) terbukti bahwa kenaikan jumlah uang elektronik (e-money) dalam transaksi digital tidak selalu diikuti oleh pertumbuhan ekonomi. Namun demikian, jumlah transaksi digital terus mengalami peningkatan walaupun nilai PDB terkontraksi. Hal ini dapat terlihat jelas dari jumlah instrumen peredaran uang elektronik yang terus meningkat. Dari penelitian ini dapat disimpulkan bahwa kenaikan jumlah uang elektronik beredar belum dapat menaikkan pertumbuhan ekonomi Indonesia secara makro. Namun demikian, transaksi digital dapat menjadi pondasi bangkitnya ekonomi Indonesia pada masa pandemi Covid-19 dan di masa depan.

\section{DAFTAR PUSTAKA}

[1] Tumpal Manik, “Analisis Pengaruh Transaksi Digitalisasi Uang Elektronik Terhadap Cashless Society Dan Infrastruktur Uang Elektronik Sebagai Variabel Pemodarasi," J. Ilm. Akunt. dan Finans. Indones., vol. 2, no. 2, pp. 27-40, 2019, doi: 10.31629/jiafi.v2i2.1714.

[2] P. Ardianto, "Tumbuh 30\%, Transaksi Digital Banking akan Tembus Rp 35.600 Triliun," 2021. https://investor.id/finance/258173/tumbu h-30-transaksi-digital-banking-akantembus-rp-35600-triliun .

[3] PrismaLink, "Pengertian dan Keuntungan Penggunaan Digital Payment,” 2021. https://www.prismalink.co.id/pengertian -dan-keuntungan-penggunaan-digitalpayment/.

[4] "Ekonomi Digital Indonesia Diprediksi Tumbuh Delapan Kali Lipat di Tahun 2030," Kemenkeu. 2021, Accessed: Sep. 22, 2021. [Online]. Available: https://www.kemenkeu.go.id/publikasi/b erita/ekonomi-digital-indonesiadiprediksi-tumbuh-delapan-kali-lipat-ditahun-2030/.

[5] D. Tapscott, The Digital Economy. USA: McGraw-Hill, 1995.

[6] B. P. Statistik, "Laporan Perekonomian Indonesia "Dampak Adanya Program Pemulihan Ekonomi Nasional (PEN) Terhadap Perekonomian Indonesia di Masa Pandemi, Katalog BPS 9199007," Jakarta, 2021.

[7] "Pengertian dan Keuntungan Penggunaan Digital Payment," PrismaLink. 2021, Accessed: Sep. 23, 2021. [Online]. Available: https://www.prismalink.co.id/pengertian -dan-keuntungan-penggunaan-digitalpayment/.

[8] T. Apriyani, "Model Pertumbuhan Ekonomi Endogen," 2018. https://yoursay.suara.com/lifestyle/2019/ 12/10/095513/dampak-uang-elektronikterhadap-perekonomian-indonesia (accessed Sep. 22, 2021).

[9] A. Murni, Ekonomi Makro. Bandung: PT. Refika Aditama, 2016.

[10] A. Saefudin, "Model Pertumbuhan Ekonomi Endogen," 2019. https://kolom.tempo.co/read/1174658/m odel-pertumbuhan-ekonomi-endogen.

[11] N. G. Mankiw, Pengantar Ekonomi Makro. Jakarta: Salemba Empat, 2013. 
[12] N. I. Nizar and A. N. Sholeh, "Peran Ekonomi Digital Terhadap Ketahanan dan Pertumbuhan Ekonomi Selama Pandemi COVID-19," J. Madani Ilmu Pengetahuan, Teknol. dan Hum., vol. 4, no. 1, pp. 87-99, 2021, doi: 10.33753/madani.v4i1.163.

[13] B. P. Statistik, "Pertumbuhan Ekonomi Indonesia Triwulan II - 2021," 2021. [Online].

Available: https://bps.go.id/indicator/169/1956/1/seri-2010-pdb-triwulanan-atas-dasarharga-konstan-menurutpengeluaran.html.

[14] Bank Indonesia, "Jumlah Uang Elektronik Beredar," 2021. [Online]. Available:

https://www.bi.go.id/id/statistik/ekonom i-keuangan/ssp/uang-elektronikjumlah.aspx.

[15] H. Kusuma, "Resesi, Krisis, dan Depresi Ekonomi apa bedanya?," 2020. https://finance.detik.com/beritaekonomi-bisnis/d-5121402/resesi-krisisdan-depresi-ekonomi-apa-bedanya (accessed Sep. 25, 2021).

[16] Kementerian Koordinator Bidang Perekonomian, "Pertumbuhan Ekonomi Triwulan II-2021 Menembus Zona Ekspansif," 2021. https://ekon.go.id/publikasi/detail/3196/ pertumbuhan-ekonomi-triwulan-ii-2021menembus-zona-ekspansif. 